\title{
EFFECT OF DIFFERENT SURFACE AND DRIP IRRIGATION SYSTEMS ON SUGAR BEET YIELD, IRRIGATION PERFORMANCES AND SOIL SALINITY AT NORTH DELTA. Sonbol, H.A. ${ }^{1}$; E.M. El-Hadidi ${ }^{1}$; M.M.Said ${ }^{2}$ and H.M. Abo El- Soud ${ }^{2}$ 1- Soil Sci. Dept., Fac. of Agric., Mansoura Univ. 2- Soil, Water and Environment Institute, Agricultural Research Center
}

\begin{abstract}
A surface drip irrigation(single lateral, SSDI, or double laterals/plant row, DSDI)) , subsurface drip irrigation (single lateral, SSSDI ,or double laterals/plant row, DSSDI),gated pipes (GP) and traditional surface irrigation(TSI) were applied with sugar beet(variety Raspoly) during the winter season 2007/2008 at Sakha Agricultural Research Station Farm, Kafr El-Sheikh Governorate, Egypt in order to study the effect of these irrigation systems on sugar beet yield, its quality, irrigation performances and soil salinity. Both drip irrigation systems included $16 \mathrm{~mm}$ diameter drip-lines, with emitters discharging about $2 \mathrm{~L} / \mathrm{h}$ and spacing $0.5 \mathrm{~m}$. The subsurface drip irrigation system was installed before the crop seeding, where its laterals $(16 \mathrm{~mm}$ drip-lines) were buried $0.6 \mathrm{~m}$ apart at $15 \mathrm{~cm}$ below soil surface so that they are not affected by the cultivation practices during the current growing season. The aluminum gated pipes (150 $\mathrm{mm}$ diameter) were located at the head of the irrigated field and connected directly with the irrigation pump.

The design of this experiment was randomized complete blocks(RCB) with six replicates.

The following findings could be summarized as follows:

The highest root, sugar yield, sucrose percentage and quality of juice were produced when sugar beet plants were irrigated by gated pipes. While the lowest root and sugar yield were achieved with irrigation by double line of subsurface drip irrigation.

- The highest content of $\mathrm{K} \%$ was obtained when sugar beet plants received the lowest amount of irrigation water. While, the lowest one was recorded with plants received the highest amount of irrigation water.

- $\mathrm{Na} \%$ and amino $\mathrm{N} \%$ in Juice: The different irrigation systems had insignificant effect on $\mathrm{Na}$ and amino $\mathrm{N} \%$ in Juice.

- Water applied was obviously affected by irrigation systems. The DSSDI system was more effective since it received the lowest amount of irrigation water (2074.8 $\left.\mathrm{m}^{3} / \mathrm{fed}\right)$ followed by SSSDI (2230.2 $\left.\mathrm{m}^{3} / \mathrm{fed}\right)$ DSSDI system $\left(2255.4 \mathrm{~m}^{3} / \mathrm{fed}\right)$. On the other hand, TSI system received the highest amount of irrigation water (3150 $\left.\mathrm{m}^{3} / \mathrm{fed}\right)$ followed by GP system $\left(2692.2 \mathrm{~m}^{3} / \mathrm{fed}\right)$

- The highest values of field water use efficiency are obtained with SSSDI or DSSDI ,respectively. While, the lowest value is given by TSI system. Also, the highest values of crop water use efficiency are achieved with SSSDI, GP and DSSDI system. The lowest values of crop water use efficiency for root are recorded with SSDI, DSDI and TSI system.

- The irrigation by GP and SSDI systems achieved the highest values of water distribution efficiency. While, subsurface drip irrigation system (single or double laterals) recorded the lowest distribution efficiency. On the other hand, surface drip irrigation system achieved the highest values of distribution uniformity with single or double laterals/plant row respectively. While, the lowest distribution uniformity value is recorded with single subsurface drip laterals.
\end{abstract}


Sonbol, H.A. et al.

- The soil salinity values are increased with depth for surface drip irrigation (single or double laterals), gated pipes and traditional surface irrigation. While with subsurface drip irrigation (single or double laterals), the values are decreased with the depth to $60 \mathrm{~cm}$ and then increased again in the last deepest layer $(60-90 \mathrm{~cm})$.

Keywords: surface and drip irrigation, sugarbeet, salinity.

\section{INTRODUCTION}

The available water in Egypt is limited by Nile water agreement with Sudan in 1959 which allowed a share of 55.5 BCM at Aswan.

With the increase of population and food requirements, the greatest challenge is striking a balance between limited water supplies and obtaining higher yield. Therefore, to make best use of water for agriculture, improving irrigation efficiency is prerequisite for the future.

It is necessary to manage available irrigation water supplies as efficiently as possible; irrigation management is one way to achieve the goal of maximizing water use efficiency.

It is a must to improve surface irrigation systems by many options have high efficiencies such as gated pipes, on-surface and subsurface drip irrigation and sprinkler irrigation systems.

In this connection, Shalhevet (1984) found that the choice irrigation system may be guided three consideration i.e. the distribution of salts and waters in the soil, crop sensitivity to foliar wetting and the extent of the damage to yield and the ease with which high salt and matric potential can be maintained in the soil.

Moore and Fitschen (1990) reported that the subsurface trickle irrigation system caused better water distribution and better water management. They also added that the net yield increased, compared with that in furrow irrigation system.

Singh-Saggu and Kaushal (1991), found that the plant root zone under trickle system remained almost salt free, while the high EC values were recorded in it under the furrow system.

El-Marazky (1996) concluded that trickle irrigation decreased water requirement by $30-40 \%$ from total seasonal consumptive use comparing to furrow system.

Abo Soliman et al (2008) reported that the grain yield of wheat and soybean crops were significantly increased with gated and concrete pipes and with shorter border length and width. Grain yield under gated and concrete pipes, respectively, were higher than under traditional field ditch by about 8.0 and $3.0 \%$ of wheat and 9.0 and $7.0 \%$ of soybean

Saied et al (2008) found that irrigation by surface drip resulted in increasing the seed yield of soybean by $18.84 \%, 37.68 \%, 17.39 \%, 11.59$ $\%$ and $4.35 \%$ compared to semi portable, gun, minisprinkler, floppy, and subsurface drip systems, respectively.

Sugar beet (Beta vulgaris, L.) plays a prominent role for sugar production in the world. However, this crop has attracted the attention in Egypt for sugar production in the last ten years only and the government is pushing hard to increase the areas those devoted to sugar beet as well as the root and sugar yield per unit area. This could be achieved through using 
the best irrigation systems and adopting agricultural practices for this important crop.

Sugar beet could be efficiently grown under a wide range of irrigation water level where it is readily adapted to limited irrigation because plants utilize deep stored soil water and recover quickly following water stress (Winter, 1980). Mohamed et al. (2000) found that the maximum root and sugar yield as well as water use efficiency ( $\mathrm{kg}$ root and / or sugar $/ \mathrm{m}^{3}$ water) were significantly obtained when sugar beet watered constantly at $65 \%$ of the field capacity.

Osman (2000) found that a feasible practice to attain water conservation and increase irrigation water use efficiency by using gated pipes for irrigation.

Jibin and Faroud (2007) found that the gated pipes system for basin irrigation can improve the uniformity of salt leaching .There is a good potential for irrigation with saline water.

Abou El Alzem (2005) showed that total soluble salts are increased significantly with surface trickle, subsurface trickle and low pressure sprinkler systems. While it decreased significantly with medium pressure sprinkler and modified furrow system. It increased significantly also with increasing distances from the emitter the sprinkler or the bottom or furrow, soil layers depths and used time for all irrigation systems. The obtained results indicated that the maximum sugar beet root yield ( 35.1 ton/fed), sucrose $(21.78 \%)$ and amount of consumptive use (559.91 $\mathrm{mm} / \mathrm{fed}$ ) were produced when using the minimum amount of irrigation water applied $(559.9 \mathrm{~mm} / \mathrm{fed})$ as an average of both studied seasons with subsurface trickle irrigation system

The current work aims to evaluate some surface and drip irrigation systems to clarify their effects on sugar beet yield, some irrigation performances and salt distribution.

\section{MATERIALS AND METHODS}

Field experiment was conducted during winter season 2007/2008 in Sakha Agricultural Research Station Farm, Kafr El-Sheikh Governorate ( $6 \mathrm{~m}$ altitude, $31^{\circ} 07^{-}$latitude and $30^{\circ} 52^{-}$longitude ). The area of $4400 \mathrm{~m}^{2}$ experimental field was divided into six plots to be occupied by the studied irrigation systems $\left(550 \mathrm{~m}^{2}\right.$ for drip each one of four systems and $1100 \mathrm{~m}^{2}$ for gated pipes and the same area for traditional systems). Each experimental plot was 16 rows, of $0.60 \mathrm{~m}$ apart for each (across the crop rows) and $55 \mathrm{~m}$ long (along of the crop rows)

The subsurface laterals were buried at a depth of $0.15 \mathrm{~m}$, so that they are not affected by plowing and other agricultural practices. The drip irrigation network consisted of a main delivery pipe $(63 \mathrm{~mm}$ in diameter). The drip laterals were $16 \mathrm{~mm}$ polyethylene pipes with in-line self-regulated emitters with discharge rate of about 2 liter $/ \mathrm{hr}$. The gated pipes are $150 \mathrm{~mm}$ diameter aluminum pipes with slide gates at $0.75 \mathrm{~m}$ spacing $\left(3.0 \mathrm{~m}^{3} / \mathrm{h}\right.$ discharge for each).The pipes are located at the head of the irrigated field across the furrows and connected directly with the water pump. 
Sonbol, H.A. et al.

So, the irrigation systems under this study are: Four drip irrigation systems and two surface irrigation systems were used in this study as follows:

1. Single surface drip irrigation lateral/crop row (SSDI).

2. Double surface drip irrigation laterals/crop row

3. Single subsurface drip irrigation lateral/crop row

4. Double subsurface drip irrigation laterals/crop row.....(DSSDI).

5. Gated pipes.

6. Traditional surface irrigation as a control.

Some chemical analysis of soil paste extract were done according to Black (1965) and some physical properties of soil were determined according to Garcia (1987) .The chemical , physical and moisture characteristics of the experimental soil are shown in Tables 1, 2 and 3 .

Table 1:Some physical and chemical properties of the experimental soil.

\begin{tabular}{|c|c|c|c|c|c|c|}
\hline \multirow{2}{*}{$\begin{array}{c}\text { Soil depth } \\
\text { (cm) }\end{array}$} & \multicolumn{3}{|c|}{ Particle size distribution (\%) } & \multirow{2}{*}{$\begin{array}{c}\text { Texture } \\
\text { class }\end{array}$} & \multirow[b]{2}{*}{ OM \% } & \multirow{2}{*}{$\begin{array}{c}\text { Total } \\
\mathrm{CaCO}_{3} \% \\
\end{array}$} \\
\hline & Sand & Silt & Clay & & & \\
\hline $0-30$ & 18.9 & 33.7 & 47.4 & Clay & 1.5 & 3.4 \\
\hline $30-60$ & 16.6 & 34.2 & 49.2 & Clay & 1.3 & 3.5 \\
\hline $60-90$ & 17.0 & 35.1 & 47.9 & Clay & 1.1 & 3.7 \\
\hline
\end{tabular}

Table 2:Soil moisture characteristics of the experimental soil.

\begin{tabular}{|c|c|c|c|c|}
\hline $\begin{array}{c}\text { Soil } \\
\text { depth(cm) }\end{array}$ & $\begin{array}{c}\text { Field capacity } \\
(\%)\end{array}$ & $\begin{array}{c}\text { Wilting } \\
\text { point(\%) }\end{array}$ & $\begin{array}{c}\text { Available } \\
\text { water(\%) }\end{array}$ & $\begin{array}{c}\text { Bulk density } \\
\left(\mathbf{g ~ c m}^{-3} \mathbf{)}\right.\end{array}$ \\
\hline $0-30$ & 42.6 & 20.4 & 22.2 & 1.14 \\
$30-60$ & 39.2 & 22.5 & 16.7 & 1.24 \\
$60-90$ & 35.7 & 20.6 & 15.1 & 1.28 \\
\hline Average & 39.17 & 21.17 & 18.00 & 1.22 \\
\hline
\end{tabular}

Table 3: Chemical analysis of soil paste extract of the experimental soil.

\begin{tabular}{|c|c|c|c|c|c|c|c|c|c|c|}
\hline \multirow{2}{*}{$\begin{array}{l}\text { depth } \\
\text { (cm) }\end{array}$} & \multirow{2}{*}{$\begin{array}{l}\begin{array}{l}E C e \\
d^{S S m^{-1}}\end{array} \\
\end{array}$} & \multicolumn{4}{|c|}{ Soluble cations meq $\mathrm{L}^{-1}$} & \multicolumn{4}{|c|}{ Soluble anions meq $\mathrm{L}^{-1}$} & \multirow{2}{*}{ SAR } \\
\hline & & $\mathrm{Na}^{+}$ & $\mathrm{K}^{+}$ & $\mathrm{Ca}^{++}$ & $\mathbf{M g}^{++}$ & $\mathrm{CO}_{3}$ & $\mathrm{HCO}_{3}{ }^{-}$ & $\mathrm{Cl}^{-}$ & $\mathrm{SO}_{4}^{-1}$ & \\
\hline $0-30$ & 2.48 & 14.8 & 0.5 & 7.2 & 3.1 & 0.0 & 1.5 & 15.2 & 8.9 & 6.52 \\
\hline & 2.36 & 13.9 & 0.5 & 6.9 & 2.9 & 0.0 & 1.7 & 14.8 & 7.7 & 6.3 \\
\hline-90 & 2.68 & 16.5 & 0.6 & 7.2 & 3.3 & 0.0 & 1.3 & 16.9 & 9.4 & 7.2 \\
\hline
\end{tabular}

Sugar beet ( Variety Raspoly ) was planted on December, $4^{\text {th }}, 2007$ and harvested on May, $20^{\text {th }}, 2008$.

All agricultural practices and fertilization rates were performed according to the traditional recommendations in North Delta area. The recommended dose of NPK chemical fertilizers for sugar beet were added( $80 \mathrm{~kg} \mathrm{~N}, 15.5 \mathrm{~kg} \mathrm{P}_{2} \mathrm{O}_{5}$ and $48 \mathrm{~kg} \mathrm{~K}_{2} \mathrm{O}$ fed $^{-1}$ ) from the same fertilizers forms.

All plots were irrigated when $50 \%$ of the available water was depleted using TDR apparatus. The yield of each replication (three crop rows by 2.33 $\mathrm{m}$ long ) was collected manually and weighed making a total harvested area of $4.2 \mathrm{~m}^{2}$ for each replication . 
- Root yield of sugar beet plants was determined for all treatments at maturity stage as ton / fed.

- Sucrose concentration and juice purity ( $\%$ ) were determined in Delta Sugar Limited Company at El - Hamoul, Kafr El-Sheikh Governorate for all treatments.

- Gross sugar yield (ton fed $\left.{ }^{-1}\right)=$ root yield (ton fed ${ }^{-1}$ ) * sucrose percentage.

Statistical analysis : the yield and yield qualities of sugar beet were subjected to the statistical analysis according to Snedecor and Cochran (1967) and the mean values compared by LSD test.

\section{Studied characters:}

1. Irrigation water applied (wd) and irrigation time:

The amounts of irrigation water applied and irrigation time (hr/plot) for each irrigation system were measured using soil moisture content just before irrigation for the required soil depth, field capacity of soil and available water discharge for each irrigation systems. The net depth of water applied for drip irrigation was determined according to Phocaides (2001) as follow:-

Net depth of irrigation water (DWs) in $m m=f(f c-w p){ }^{*} d b * D s * P$.

While the net depth of water applied for surface irrigation was determined according to the following equation :-

Net depth of irrigation water (DWs) in $\mathrm{mm}=\mathrm{f}(\mathrm{fc}-\mathrm{wp}){ }^{*} \mathrm{db}{ }^{*} \mathrm{Ds} / 100$. Where :

fc = field capacity $(\%)$.

$\mathrm{f}=$ permissible depletion

Ds = soil layer $(\mathrm{cm})$

$$
\begin{aligned}
& \mathrm{wp}=\text { wilting point }(\%) . \\
& \mathrm{db}=\text { bulk density }\left(\mathrm{g} \mathrm{cm}^{-3}\right) \\
& \mathrm{P}=\text { ground cover }(\%)
\end{aligned}
$$

In addition, the discharge of the dripper, gates (of gated pipes) and water pump were measured to calculate the irrigation time for each irrigation system.

\section{Water consumptive use ( $\mathrm{CU})$ :}

It was calculated according to Hansen et al., (1979)

$$
\mathrm{CU}=\frac{\theta_{2}-\theta_{1}}{100} \times \mathrm{Db} \times \mathrm{D}
$$

Where :

$\mathrm{CU}=$ Actual water consumptive use of the growing plants, $\mathrm{cm}$ depth

$\theta_{1}=$ Mean Soil moisture percentage for the $60 \mathrm{~cm}$ soil depth, 48 hours before the next irrigation.

$\theta_{2}=$ Soil moisture content ( $\left.\%\right)$ after irrigation.

$\mathrm{Db}=$ Bulk density $\left(\mathrm{g} \mathrm{cm}^{-3}\right)$.

$\mathrm{D}=$ Layer depth in $\mathrm{cm}$.

3. Irrigation application efficiency ( Ea ) :

Irrigation application efficiency for each treatment was computed according to Downy ( 1970 ) using the following equation :-

$$
\mathrm{Ea}(\%)=\frac{W s}{W d} \times 100
$$


Where :

$\mathrm{Ea}=$ water application efficiency $(\%)$.

$W s=$ water stored in the effective root zone $(\mathrm{cm})$.

$\mathrm{Wd}=$ water applied with different treatments $(\mathrm{cm})$.

\section{Water distribution efficiency :} as follows :

Water distribution efficiency was calculated according to James (1988)

Where :

$$
E d=(1-y / d) \times 100
$$

$\mathrm{Ed}=$ water distribution efficiency $(\%)$.

$\mathrm{d}=$ average depth of soil water stored along the furrow during the irrigation.

$y=$ average numerical deviation from $d$.

\section{Crop water use efficiency (CWUE):}

It was calculated in $\mathrm{kg} / \mathrm{m}^{3}$ for different irrigation systems as follow:

$$
\text { CWUE }=\frac{Y}{\text { Wcu }}
$$

Where : $Y=$ grain yield $(\mathrm{kg} / \mathrm{fed}$.)

$$
\mathrm{Wcu}=\text { total water consumed in } \mathrm{m}^{3} / \text { fed. }
$$

\section{The field water use efficiency ( FWUE):}

It was calculated in $\mathrm{kg} / \mathrm{m}^{3}$ for different irrigation systems to clarify how much $\mathrm{kg}$ yield is produced from one cubic meter applied (Michael , 1978) as follow:

Where :

$$
\mathrm{FWUE}=\mathrm{Y} / \mathrm{Wa}
$$

$\mathrm{Y}=$ total yield produced $(\mathrm{kg} / \mathrm{fed}$.$) .$

$\mathrm{Wa}=$ total applied water $\left(\mathrm{m}^{3} /\right.$ fed. $)$.

\section{Soil salinity distribution.}

Soil salinity distribution was evaluated for each treatment.

\section{RESULTS AND DISCUSSION}

\section{Sugar beet yield and it's quality 1- yield of root and sugar :}

Results presented in Table 4 show the root yield in ton/fed and sugar yield in ton/fed, as affected by different irrigation systems. It is obvious from the results that root yield and sugar yield were increased significantly when sugarbeet was subjected to irrigation with gated pipes method followed by traditional surface irrigation and the reduction in root and sugar yield were more pronounced with irrigation by double lines of surface drip irrigation and single line of surface drip irrigation and double line of sub surface drip irrigation, respectively. Moreover, the highest root yield (19.27 ton/fed) and sugar yield (2.57 ton/fed) were produced when sugar beet plants were irrigated by gated pipes. While, the lowest root and sugar yield were achieved with irrigation by double line of subsurface drip irrigation. The increase in root 
yield by irrigation with gated pipes might be attributed to be the favorable effect of maintaining soil moisture in the effective root zone.

\section{2- Sucrose percentage:}

The sucrose percentage in sugar beet roots is significantly affected by the different irrigation systems. The highest sugar content in the roots is achieved with gated pipes (13.32\%) and traditional surface irrigation $(13.42 \%)$. While the lowest sugar content is recorded with single lateral of surface drip irrigation (12.13\%).

These results are in a good agreement with those obtained by Abo Soliman et al. (2008) and Saied et al. (2008).

\section{3. $\mathrm{K} \%$ in juice :}

Data in Table 4 show that the different irrigation systems had highly significant effect on $\mathrm{K} \%$. The obtained data revealed that the highest value is recorded with SSDI system ( $6.88 \%)$. While the lowest values of $\mathrm{K}$ content in root juice were found with surface irrigation systems ( $5.85 \%$ with GP and $5.95 \%$ with TSI system ) .

It is clear that the highest content of $\mathrm{K} \%$ was obtained when sugarbeet plants received the lowest amount of irrigation water. While, the lowest one was recoded with plants received the highest amount of irrigation water.

\section{Na and amino N\% in juice :}

Data in Table 4 declared that the different irrigation systems had insignificant effect on $\mathrm{Na}$ and amino $\mathrm{N} \%$ in juice .

\section{Quality of juice :}

The obtained results in Table 4 indicate that the quality of juice is highly significantly affected by irrigation systems. Irrigation by gated pipes $(67.3 \%)$ and traditional surface irrigation ( $66.3 \%$ ) have the highest quality level, respectively, While the lowest juice quality is recorded with SSDI system $(56.9 \%)$. It could be observed from the data that positive relation is found between sucrose content (\%) and juice quality while a negative relation is found between both $\mathrm{K} \%$ and $\mathrm{Na} \%$ with both of sucrose content and the quality of juice. Also, the values of these parameters with different irrigation systems may be related to the amounts of water applied with each system .

The obtained results are in a close agreement with those found by Winter (1990) and Abo Soliman et al ( 1996 ) .

Table 4: Sugar beet yield and its quality as affected by studied irrigation systems.

\begin{tabular}{|c|c|c|c|c|c|c|c|}
\hline $\begin{array}{c}\text { Irrigation } \\
\text { systems }\end{array}$ & $\begin{array}{c}\text { Root } \\
\text { (ton/fed) }\end{array}$ & $\begin{array}{c}\text { Sugar } \\
(\%)\end{array}$ & $\begin{array}{c}\text { Sugar } \\
\text { (ton/fed) }\end{array}$ & $\begin{array}{c}\mathbf{K} \\
(\%)\end{array}$ & $\begin{array}{c}\text { Na } \\
(\%)\end{array}$ & $\begin{array}{c}\text { Amino N } \\
\text { (\%) }\end{array}$ & $\begin{array}{c}\text { Quality } \\
(\%)\end{array}$ \\
\hline SSDI & 16.93 & 12.13 & 2.054 & 6.88 & 5.67 & 2.94 & 56.9 \\
\hline DSDI & 16.82 & 12.81 & 2.155 & 6.14 & 5.42 & 2.88 & 64.6 \\
\hline SSSDI & 18.83 & 12.92 & 2.430 & 6.57 & 5.40 & 2.89 & 58.8 \\
\hline DSSDI & 16.25 & 12.43 & 2.028 & 6.22 & 5.36 & 2.84 & 61.9 \\
\hline GP & 19.27 & 13.32 & 2.567 & 5.85 & 5.20 & 2.92 & 67.3 \\
\hline TSI & 18.39 & 13.42 & 2.478 & 5.95 & 5.51 & 3.00 & 66.3 \\
\hline F test & $\star *$ & $\star$ & $\star *$ & $\star *$ & ns & ns & $\star *$ \\
\hline LSD 0.05 & 1.16 & 0.521 & 0.207 & 0.435 & - & - & 2.208 \\
\hline LSD 0.01 & 1.60 & - & 0.286 & 0.602 & - & - & 3.053 \\
\hline
\end{tabular}


Sonbol, H.A. et al.

Some water relations:

1- Amount of water applied:

Data in Table 5 indicated the amount of water applied to different irrigation systems. These values were found to be 2310, 2255.4, 2230.2, 2074.8, 2692.2, and $3150 \mathrm{~m}^{3} / \mathrm{fed}$ for SSDI, DSDI, SSSDI, DSSDI, GP and TSI systems, respectively. The lowest values are achieved under DSSDI system.

On the other hand, the highest value was recorded with TSI system. The reduction in water applied may be due to the drip irrigation method which reduces the deep percolation, evaporation and runoff.

It is worthy to mention, that water saving percentages were 26.67, 28.40, 29.20, 34.13 and $14.53 \%$ under SSDI, DSDI, SSSDI, DSSDI and GP compared to TSI. These results are in agreement with those obtained by ElMarazky (1996) who concluded that trickle irrigation decreased water requirements by $30-40 \%$ comparing to furrow irrigation system.

\section{2- Actual water consumptive use for sugar beet:}

From the obtained data, it could be noticed that the highest value of water consumptive use by sugar beet is recorded with traditional surface irrigation system, while the lowest value is detected with DSSDI system.

The mean values of water consumptive use were found to be 2041.2, 1995.0, 1965.6, 1839.6, 2125.2 and $2146.2 \mathrm{~m}^{3} / \mathrm{fed}$ for SSDI, DSDI, SSSDI, DSSDI, GP and TSI systems, respectively (Table 5).

Table 5:Some water relations as affected by different irrigation systems

\begin{tabular}{|c|c|c|c|c|c|c|}
\hline $\begin{array}{c}\text { Irrigation } \\
\text { system }\end{array}$ & $\begin{array}{l}\text { Root yield } \\
\left(\text { kg fed }^{-1}\right)\end{array}$ & $\begin{array}{c}\text { Water } \\
\text { applied } \\
\left(\mathrm{m}^{3} \mathrm{fed}^{-1}\right)\end{array}$ & $\begin{array}{c}\text { Water } \\
\text { saving } \%\end{array}$ & \begin{tabular}{|c|} 
Water \\
consum. use \\
$\left(\mathrm{m}^{3} \mathrm{fed}^{-1}.\right)$
\end{tabular} & $\begin{array}{l}\text { FWUE}^{\star} \\
\left(\mathrm{kg} \mathrm{m}^{-3}\right)\end{array}$ & $\begin{array}{l}\text { CWUEE } \\
\left(\mathrm{kg} \mathrm{m}^{-3}\right)\end{array}$ \\
\hline SSDI & 16930 & 2310 & 26.67 & \begin{tabular}{|l|}
2041.2 \\
\end{tabular} & 7.33 & 8.29 \\
\hline DSDI & 16820 & 2255.4 & 28.4 & 1995 & 7.46 & 8.43 \\
\hline SSSDI & 18830 & 2230.2 & 29.2 & 1965.6 & 8.44 & 9.58 \\
\hline DSSDI & 16250 & 2074.8 & 34.13 & 1839.6 & 7.83 & 8.83 \\
\hline GP & 19270 & 2692.2 & 14.53 & 2125.2 & 7.16 & 9.07 \\
\hline TSI & 18390 & 3150 & & 2146.2 & 5.84 & 8.57 \\
\hline
\end{tabular}

* FWUE: Field water use efficiency.

${ }^{* *}$ CWUE: Crop water use efficiency.

\section{3-Field and crop water use efficiencies:}

Data of field and crop water use efficiencies are presented in Table 5. These efficiencies determine the capability of plants to convert the applied or consumed water to crop yield. The average values of field water use efficiency (FWUE) are 7.33,7.46, 8.44,7.83, 7.16 and $5.84 \mathrm{~kg} \mathrm{root} / \mathrm{m}^{3}$ of water applied for SSDI, DSDI, SSSDI, DSSDI, GP and TSI systems, respectively. So, the highest value of FWUE $\left(8.49 \mathrm{~kg} / \mathrm{m}^{3}\right)$ is obtained with SSSDI. While, the lowest value $\left(5.84 \mathrm{kgm}^{-3}\right)$ is given by TSI system. Concerning the crop water use efficiency (CWUE) in terms of $\mathrm{kg} \mathrm{root} / \mathrm{m}^{3}$ of water consumed, the data revealed that the highest values are achieved with SSSDI, GP and DSSDI systems $\left(9.58,9.07\right.$ and $\left.8.84 \mathrm{~kg} / \mathrm{m}^{3}\right)$, respectively.

On the contrary, the lowest values of CWUE for root are recorded with SSDI, DSDI and TSI systems $\left(8.30,8.44\right.$ and $8.57 \mathrm{~kg} \mathrm{~m}^{-3}$, respectively). 
These results are in somewhat agree with those obtained by Osman (2000) and El-Hendawy et al. (2008).

4- Irrigation application efficiency (\%):

Water application efficiency is one of the most important criteria used to describe field irrigation efficacy. The high value of water application efficiency means less values of deep percolation below the crop root zone and surface runoff at the tail end of furrows. Generally, irrigation application efficiency value increases as the amount of water applied decreases each irrigation.

The calculated values of water application efficiency as affected by different irrigation systems are presented in Table 6 . The average values are 90.6, 92.3, 90.8, 96.2, 79.5 and $71.7 \%$ for SSDI , DSDI , SSSDI , DSSDI ,GP and TSI systems, respectively (Table 6). It is obvious from the data that the maximum values of water application efficiency $(96.2 \%)$ are obtained from DSSDI system. The minimum irrigation application efficiency $(71.7 \%)$ is obtained from TSI system. These findings are for somewhat in harmony with those obtained by Osman ( 2002) .

5-Water distribution efficiency (DE\%) and distribution uniformity(DU \%):

Water distribution efficiency and distribution uniformity as affected by different irrigation systems are listed in Table 6 .The obtained results revealed that the gated pipes system achieved the highest value of DE (92.6). While subsurface drip irrigation system (single or double laterals) recorded the lowest DE value $(74.5 \%)$.

Table 6 : Irrigation application efficiency, water distribution efficiency and distribution uniformity as affected by different irrigation systems.

\begin{tabular}{|c|lc|c|c|c|}
\hline No & \multicolumn{2}{|c|}{ Irrigation systems } & $\begin{array}{c}\text { Irrigation } \\
\text { application } \\
\text { efficiency (\%) }\end{array}$ & DE \% & DU \% \\
\hline 1 & Single surface drip irrigation & 90.6 & 88.8 & 94.4 \\
\hline 2 & Double surface drip irrigation (SSI) & (DSDI) & 92.3 & 87.3 & 97.2 \\
\hline 3 & Single subsurface drip irrigation (SSSDI) & 90.8 & 74.5 & 82.6 \\
\hline 4 & Double subsurface drip irrigation (DSSDI) & 96.2 & 75.3 & 87.7 \\
\hline 5 & Gated pipes & $7 \mathrm{GP})$ & 79.5 & 92.6 & 89.0 \\
\hline 6 & Traditional surface irrigation (TSI) & 71.7 & 89.0 & 86.0 \\
\hline
\end{tabular}

On the other hand, surface drip irrigation system achieved the highest values of DU (94.4 and $97.2 \%$ with single or double laterals/plant row, respectively). Meanwhile, the lowest DU value is recorded with single subsurface drip laterals (82.6\%). Therefore, surface drip irrigation is the suitable system especially with double laterals/plant row since it achieved a typical soil moisture uniformity (DE or DU values). While the soil moisture distribution value is not satisfied with subsurface drip irrigation systems where low values of DE and DU parameters are obtained.

This trend of these results are in agreement with those obtained by Jibin and foroud (2007).

6. Soil salinity :

The results of soil salinity after harvesting of sugar beet at head, middle and end of fields as affected by different irrigation systems are shown in 


\section{Sonbol, H.A. et al.}

Table 7 and Figs 1-6. The obtained data revealed that the ECe values in different soil depths under different irrigation systems are lower than $4 \mathrm{dSm}^{-1}$. It could be observed from the obtained data that the differences in ECe mean values for different irrigation systems are relatively small. The values of ECe are increased with the depth for surface drip irrigation ( single or double laterals ), gated pipes and traditional surface irrigation while with subsurface drip irrigation ( single or double laterals) the ECe values are decreased with the depth to $60 \mathrm{~cm}$ and then increased again in the last deepest layers (60$90 \mathrm{~cm})$.

Table 7: Soil salinity distribution under different irrigation systems after harvesting of sugar beet crop.

\begin{tabular}{|c|c|c|c|c|c|c|}
\hline \multirow{2}{*}{$\begin{array}{c}\text { Irrigation } \\
\text { system }\end{array}$} & \multirow{2}{*}{$\begin{array}{c}\text { Depth } \\
(\mathrm{cm})\end{array}$} & \multicolumn{3}{|c|}{$\mathrm{EC}, \mathrm{dSm}^{-1}$} & \multirow{2}{*}{ Mean } & \multirow{2}{*}{$\begin{array}{c}\text { Water applied } \\
\mathrm{M}^{3} / \text { fed }\end{array}$} \\
\hline & & Field head & Middle & End & & \\
\hline \multirow{4}{*}{$\begin{array}{c}\text { Single surface } \\
\text { drip } \\
\text { (SSDI) }\end{array}$} & $0-30$ & 2.55 & 1.89 & 2.21 & 2.22 & \\
\hline & $30-60$ & 2.73 & 2.70 & 2.19 & 2.54 & \\
\hline & $60-90$ & 2.19 & 2.48 & 2.25 & 2.31 & \\
\hline & Mean & 2.49 & 2.35 & 2.22 & 2.35 & 2308 \\
\hline \multirow{4}{*}{$\begin{array}{c}\text { Double surface } \\
\text { drip } \\
\text { (DSDI) }\end{array}$} & $0-30$ & 2.55 & 1.77 & 1.58 & 1.97 & \\
\hline & $30-60$ & 1.95 & 2.78 & 1.94 & 2.22 & \\
\hline & $60-90$ & 1.71 & 3.00 & 1.89 & 2.20 & \\
\hline & Mean & 2.07 & 2.52 & 1.80 & 2.13 & 2255 \\
\hline \multirow{4}{*}{$\begin{array}{c}\text { Single } \\
\text { subsurface drip } \\
\text { (SSSDI) }\end{array}$} & $0-30$ & 3.57 & 1.25 & 3.12 & 2.65 & \\
\hline & $30-60$ & 2.19 & 2.01 & 1.71 & 1.97 & \\
\hline & $60-90$ & 3.09 & 2.17 & 2.68 & 2.65 & \\
\hline & Mean & 2.95 & 1.81 & 2.50 & 2.42 & 2231 \\
\hline \multirow{4}{*}{$\begin{array}{c}\text { Double } \\
\text { subsurface drip } \\
\text { (DSSDI) }\end{array}$} & $0-30$ & 3.15 & 3.18 & 2.63 & 2.99 & \\
\hline & $30-60$ & 2.76 & 1.75 & 2.05 & 2.19 & \\
\hline & $60-90$ & 3.59 & 1.66 & 1.95 & 2.40 & \\
\hline & Mean & 3.17 & 2.20 & 2.21 & 2.52 & 2074 \\
\hline \multirow{4}{*}{$\begin{array}{l}\text { Gated pipe } \\
\text { (GP) }\end{array}$} & $0-30$ & 1.59 & 1.65 & 1.88 & 1.71 & \\
\hline & $30-60$ & 2.00 & 2.10 & 1.91 & 2.00 & \\
\hline & $60-90$ & 3.15 & 1.59 & 2.04 & 2.26 & \\
\hline & Mean & 2.25 & 1.78 & 1.94 & 1.99 & 2694 \\
\hline \multirow{4}{*}{$\begin{array}{c}\text { Traditional } \\
\text { surface } \\
\text { irrigation(TSI) } \\
\end{array}$} & $0-30$ & 1.46 & 1.67 & 1.65 & 1.59 & \\
\hline & $30-60$ & 2.51 & 1.76 & 1.50 & 1.92 & \\
\hline & $60-90$ & 2.37 & 1.43 & 1.32 & 1.71 & \\
\hline & Mean & 2.11 & 1.62 & 1.49 & 1.74 & 3250 \\
\hline
\end{tabular}

In the top layer, the highest ECe values are observed with the subsurface drip system with single or double laterals/ plant row (2.65 and $2.99 \mathrm{dSm}^{-1}$, respectively), but the lowest ECe values are detected with the traditional surface irrigation and gated pipes systems $\left(1.59\right.$ and $1.71 \mathrm{dSm}^{-1}$, respectively). In case of the mean values of ECe for each irrigation system (as the mean of the three layers), the highest mean values are obtained with subsurface drip irrigation (2.42 and $2.52 \mathrm{dSm}^{-1}$ for the single or double laterals / plant row, respectively) . 

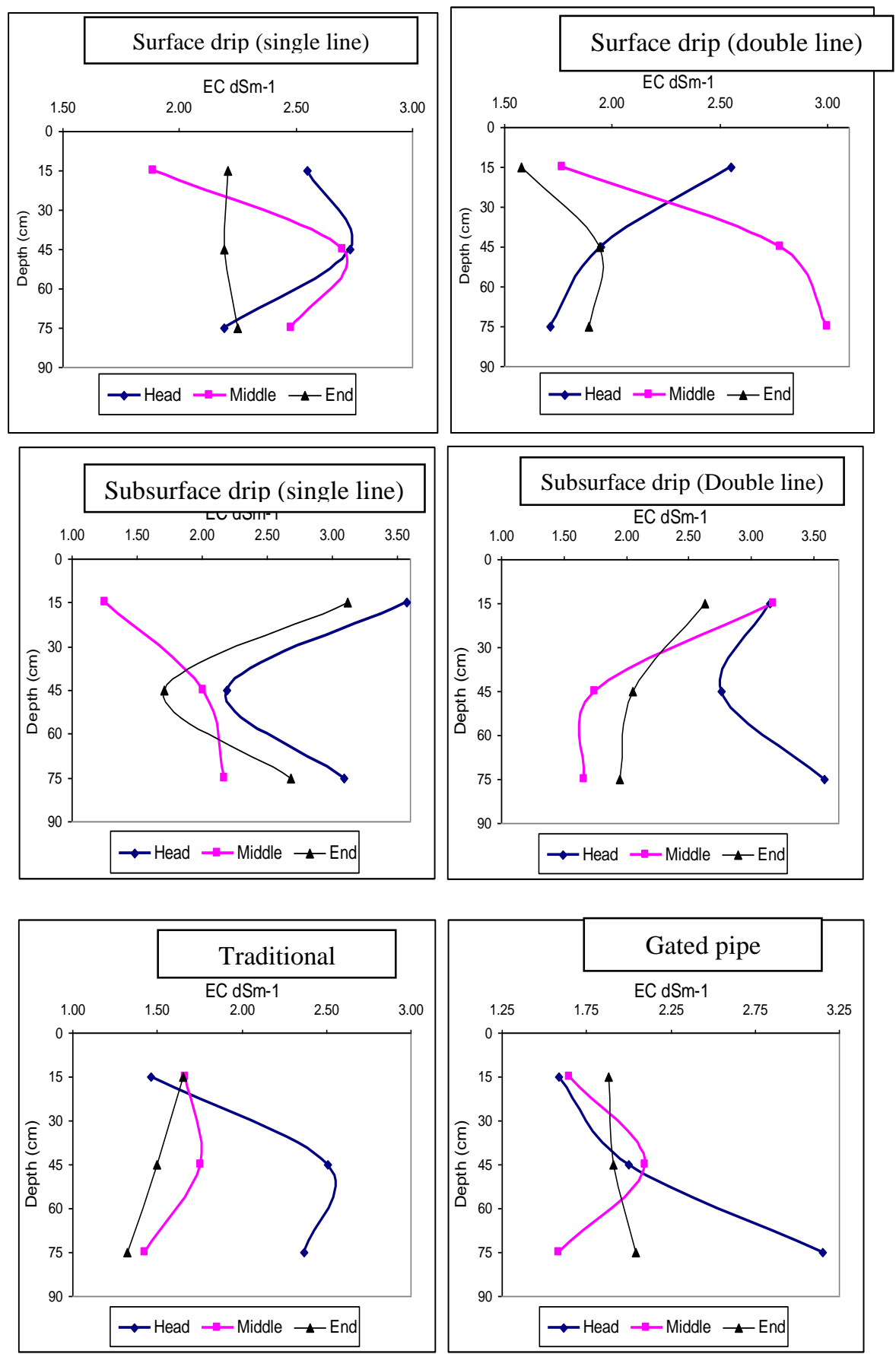

Fig 1-6: Soil salinity distribution under different irrigation systems after harvesting of sugar beet. 
Sonbol, H.A. et al.

Meanwhile, the lowest mean values of ECe are achieved with the gated pipes and traditional surface irrigation systems (1.74 and $1.99 \mathrm{dSm}^{-1}$, respectively). On the other hand, the mean value of ECe with the surface drip irrigation system is slightly lower than that recorded with the subsurface drip system (2.24 and $2.47 \mathrm{dSm}^{-1}$, respectively). This trend may be attributed to the amounts of irrigation water applied with each irrigation system.

These findings are in a good agreement with those observed by ElSharkawy, Amal (2001), and Saied et al.(2008) .

\section{Conclusion}

It can be recommended to use gated pipes as modified surface irrigation method to irrigate heavy clay soils especially under condition of salt affected soils, while subsurface drip irrigation can be used properly in case of water shortage.

\section{REFERENCES}

Abo Soliman M.S.M. , M.A. Ghazy , S.A. Abd El-Hafez and F.N. Mahrous (1996) :Effect of soil moisture depletion levels and time of withholding irrigation on yield and quality of sugar beet and water use efficiency. $J$. Agric. Res. Tanta Univ., 22 (1): 222-228

Abo Soliman M.S.M. , H. A. Shams El-Din , M.M. Saied, S.M. El-Barbary , M.A. Ghazy and M.I El-Shahawy (2008) :Impact of field irrigation management on some irrigation efficiencies and production of wheat and soybean crops. Zagazig J. Agric. Res. , 35(2) : 363-381

Abou El Azem, A.M. (2005). Salinity control and water management under different irrigation systems. Water Science. The issue 38, Oct. 2005. pp $31: 42$.

Black , C.A. (1965). "Methods of Soil Analysis". Amer. Soc. Agron. Inc. , Madison ,Wisconsin , U.S.A.

Downy ; LA(1970). Water use by maize as three plant densities , paper , 33 , FAO, Room .

EL- Hendawy , S , E . Abd EL Lattief, E.A., Mohamed, S. Ahmed and U. Schmidhaltei (2008). Irrigation rate and plant density effects on yield and water use efficiency of drip - irrigated corn . Agriculture water management, (2008), Vol , 95 , Issue; pages ; 836 - 844.

El - Marazky ; M.S.A.(1996).Cotton Production under trickle irrigation in comparison with traditional systems . Ph.D Thesis, Faculty of Agric (Moshtohor), Zagazig Univ, (Benha branch ).

El-Sharkawy ,F.B.,Amal (2001):Studies on some problems of new irrigation systems. Ph.D. Thesis, Faculty of Agriculture, Minufiya University.

Garcia , G.(1978). Soil Water Engineering Laboratory Manual. Colorado State Univ. Dept. of Agric. and chemical engineering. Fort Collins, Colorado, 80523.

Hansen, V.W., O.W. Israelsen and Q.E Stringrarm (1979) . Irrigation principles and Practices , 4 Edition, Johen Willy and Sons. 
James, L. G. (1988). Principles of farm irrigation system design. John willy sons (ed), New York PP - 543.

Jibin $\mathrm{Li}$ and N. Foroud (2007).Evaluation of a gated pipe basin irrigation method in China.

http://www.geocities.com/ResearchTriangle/Thinktank/2097/gatedpipe. htm $06 / 04 / 22$

Michael, A.M. (1978). Irrigation theory and practice. Vikas Publishing House, New Delhi, 1978.

Moore, R. and J. Fitschen (1990). The drip irrigation revolution in the Hawauan sugar can industry. Proceeding of the third national irrigation sympositum. IA. ASAF. PP. 223-227.

Mohamed, K.A. ; A.M.A. El-Shafai and I.H. El-Geddawy (2000). Effect of sowing pattern and irrigation on yield and quality of sugar beet. Egypt. J. Appl. Sci., 15 (2): 56-67.

Osman, H.E. (2000) . Gated Pipe Techniques for Improved Surface Irrigation $8^{\text {th }}$ conf., Agric., Dev., Res., Fac. Agric., Ain Shames Univ., Cairo. Nov , 20-22, 2000 .

Osman , H.E (2002) . Evaluation of surface irrigation by using gated pipes techniques on a field crops and old horticultural farms. Annals Agric . Sci , Vol : 47-, Fuc . Agric ; Ain shames Univ, Egypt .

Phocaides , A. (2001). Handbook on pressurized irrigation techniques. Food and Agriculture Organization of the United Nations, Rome

Saied , M.M. ; Ragab , M.M. ; El-Barbary , S.M. and M.I.,El-Shahawy(2008). Effect of pressurized irrigation system on soybean and flax yields and some water relations in old lands. Misr J. Ag. Eng. , 25(1): 87-101 .

Shalhevet, J. (1984). Management of irrigation with brackish water. I. Soil salinity under irrigation processes and management. Shainberg and Shalhevet (eds.), springer-verlag. 229-317.

Singh-Saggu, S. and M.P. Kaushal (1991). Fresh and saline water irrigation through drip and furrow method. International J. Tropical Agri., 9 (3): 194-202.

Snedecor, D.A. and W.C. Chocran (1967). Statistical Methods 6th ed, Oxford and IBH . publishing Co., Calcutta, India.

Winter, R.S. (1980). Suitability of sugar beet for limited irrigation in a semiarid climate. Agron. J., 72 (1): 118-123. 
Sonbol, H.A. et al.

تأثثير بعض نظم الري السطحي والري بالتتقيط على محصول بنجر السكر وكفاءات

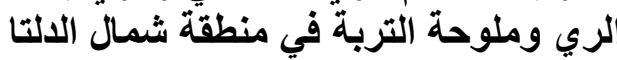

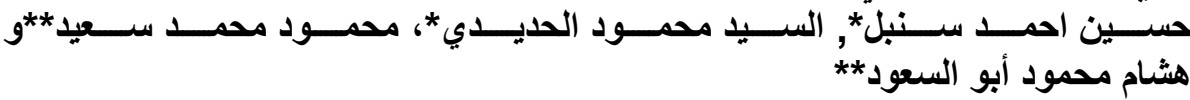

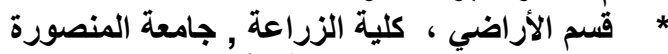

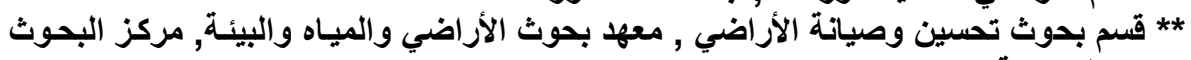
الزراعية

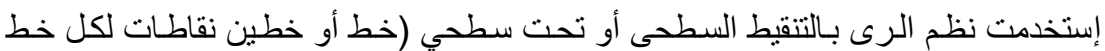

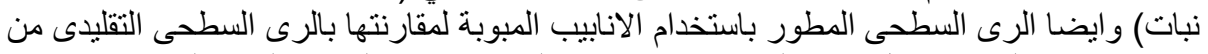

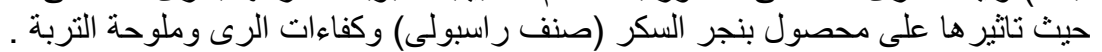

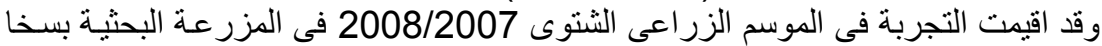

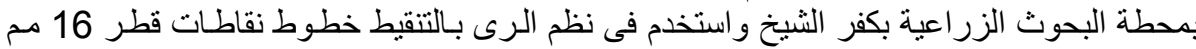

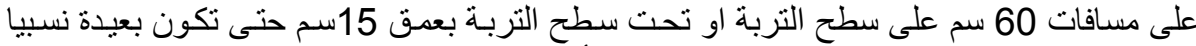

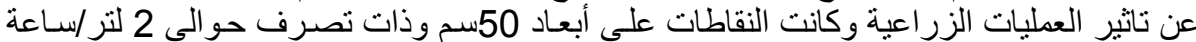

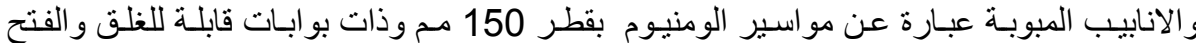

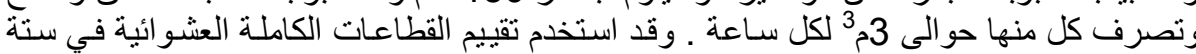

ويمكن تلخيص النتائج المتحصل عليها فيما يلى :-

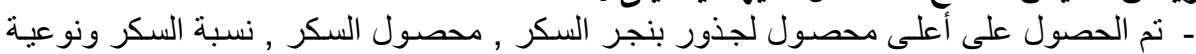

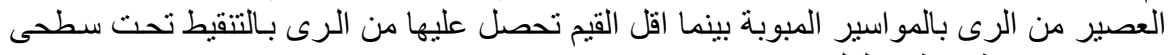

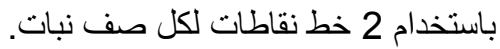

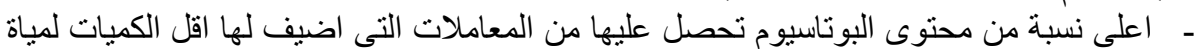

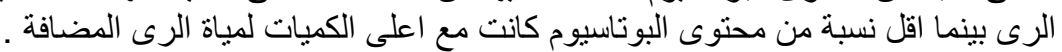

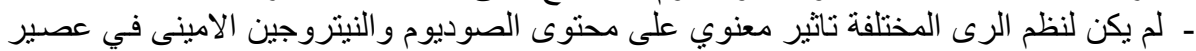

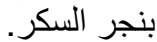

ـ ـ تأترت كميات مياه الري المضافة بنظم الرى المختلفة حيث استقبل نظام الرى بالتتقيط تحت سطحى ذو خطين نقاطات لكل خط نبات اقل الكيات الكميات من مياة الرى المضافة يليها الريا الرى بالتنقيط

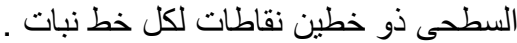

ومن جهة أخرى فـان الري السطحي التقليدي حقق أعلى القيم من كميـات ميـاة الرى

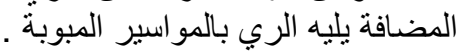

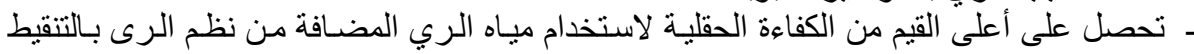

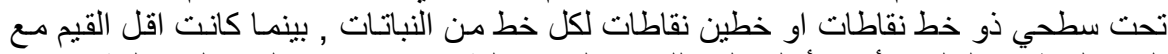

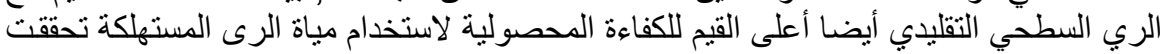

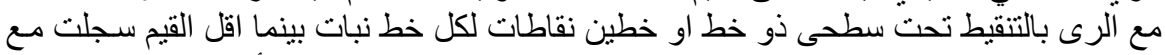
الرى بالتنقيط السطحي سواء كان خط او خط نقاطـات لكل خط نبات و أيضـا الرى السطى

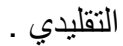
ـ ـ الرى بالمو اسير المبوبة والرى بالتتقيط السطحى ذو خطين نقاطات حقق اعلى القيم لكفاءة توزيع

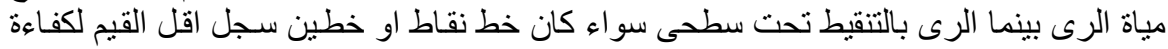

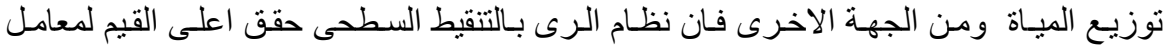

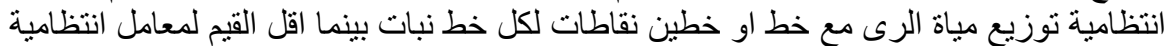
توزيع مياه الرى سجلت مع الرى بالتتقيط تحت سطحي ذو خط نقاط نطات . 
J. of Soil Sciences and Agricultural Engineering, Vol. 1 (4), April, 2010

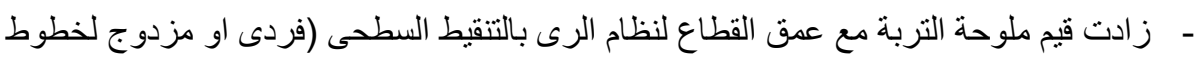

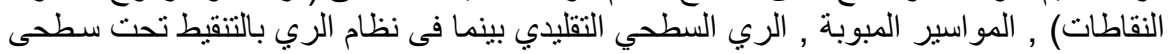

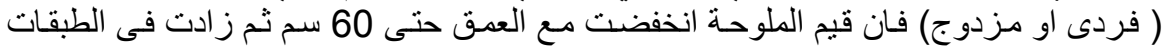

كلية الزراعة - جامعة المنصورة مركز البحوث الزراعية
قام بتحكيم البحث

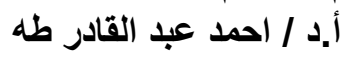
أ.د / أد / محمد إبراهيم مليحة طية 